\title{
STRESS AND COPING STRATEGIES IN A SAMPLE OF SOUTH AFRICAN MANAGERS INVOLVED IN POST-GRADUATE MANAGERIAL STUDIES
}

\author{
JUDORA J. SPANGENBERG \\ MARK R. ORPEN-LYALL \\ Department of Psychology \\ University of Stellenbosch
}

\begin{abstract}
To examine the relationships between stress levels and, respectively, stressor appraisal, coping strategies and biographical variables, 107 managers completed a biographical questionnaire, Experience of Work and Life Circumstances Questionnaire, and Coping Strategy Indicator. Significant negative correlations were found between stress levels and appraisal scores on all work-related stressors. An avoidant coping strategy explained significant variance in stress levels in a model also containing social support-seeking and problem-solving coping strategies. It was concluded that an avoidant coping strategy probably contributed to increased stress levels. Female managers experienced significantly higher stress levels and utilized a social support-seeking coping strategy significantly more than male managers did.
\end{abstract}

\section{OPSOMMING}

Om die verband tussen stresvlakke en, onderskeidelik, taksering van stressors, streshanteringstrategieë en biografiese veranderlikes te ondersoek, het 107 bestuurders 'n biografiese vraelys, Ervaring van Werk- en Lewensomstandighedevraelys en Streshanteringstrategieskaal voltooi. Beduidende negatiewe korrelasies is aangetref tussen stresvlakke en takseringtellings ten opsigte van alle werkverwante stressors. 'n Vermydende streshanteringstrategie het beduidende variansie in stresvlakke verklaar in 'n model wat ook sosiale ondersteuningsoekende en probleemoplossende streshanteringstrategieë ingesluit het. Die gevolgtrekking is bereik dat 'n vermydende streshanteringstrategie waarskynlik bygedra het tot verhoogde stresvlakke. Vroulike bestuurders het beduidend hoër stresvlakke ervaar en het 'n sosiale ondersteuningsoekende streshanteringstrategie beduidend meer gebruik as manlike bestuurders.

In South Africa more than R500 million is lost annually through absenteeism and loss of productivity as a result of stress ("Executive stress", 1991), with South African managers suffering from high levels of job stress (Strümpfer, 1989; Van $\mathrm{Zyl}, 1993)$. Occupational stress theorists suggest that destructive outcomes such as psychological distress, absenteeism, physical illness and poor work performance are caused by a combination of individual characteristics and characteristics of the work environment (Beehr, 1995; Katz \& Kahn, 1978).

According to Lazarus and Folkman's (1984) and Cox and MacKay's (1981) transactional model, stress is primarily the result of one's perception of risk factors in the environment and one's assessment of whether personal resources will enable one to meet the environmental challenges or whether, on the other hand, one will become overwhelmed by environmental threats. According to the transactional model, coping with stress consists of the individual's constantly changing cognitive and behavioural efforts to handle internal and external stressors appraised as overwhelming his or her personal resources (Lazarus \& Folkman, 1984). The concept of coping has received much attention amongst researchers recently, especially as a result of the movement away from the pathogenic to the salutogenic paradigm, an approach which focuses on factors that have the potential to maintain and even enhance psychological well-being and homeostasis within the context of a stressful environment (Antonovsky, 1990, 1991; Holahan \& Moos, 1990; Strümpfer, 1990).

Despite the lively interest in coping, there is still a paucity of stress management interventions in the workplace (Daniels, 1996). According to Daniels, the view exists that managers are not concerned with the risks of occupational stress to health and job performance. Daniels points out that a psychometric view and a cultural view exist with regard to risk perception. The psychometric view suggests that managers may underestimate the risks associated with stress. The cultural view suggests that managers may consider stress management to be

Requests for reprints should be addressed to: J.J. Spangenberg, Department of Psychology,

University of Stellenbosch, Private Bag X1, Matieland, 7602 inappropriate, since individuals, not organizations, should be responsible for coping with stress. It is essential that lack of managerial interest in stress management should be addressed. Publications on coping with stress, with an emphasis on the detrimental effect of destructive coping strategies, may encourage managers to actively manage the risks of occupational stress - also in themselves.

Every individual uses certain basic coping strategies to cope with stress (Smyth \& Williams, 1991). Coping strategies can be classified as being either problem-focused or emotion-focused (Terry \& Callan, 1997). Problem-focused strategies are directed towards managing the stressful situation, whereas emotion-focused strategies focus on dealing with the associated level of emotional distress, for instance, by relying on avoidant or escapist strategies (London, 1998; Terry \& Callan, 1997). London (1998) also refers to the importance of social support in the workplace, for instance the extent to which managers, supervisors and co-workers encourage and support the acquisition and use of new job-related knowledge and skills. Seeking social support thus constitutes an important coping strategy. On the basis of Lazarus and Folkman's transactional model, Amirkhan $(1990,1994)$ classified coping strategies into three basic modes of coping with stress, namely problem-solving, avoidant and social support-seeking strategies. Amirkhan's model was used in the present study.

A number of empirical studies dealing specifically with managers' coping strategies have been reported in the international research literature. One such study was conducted by Terry and Callan (1997), who examined the predictors of adjustment to organizational change in 140 male middle managers and supervisors involved in a large-scale public sector integration and the accompanying internal reorganization. Terry and $\mathrm{Cal}-$ lan measured coping strategies by means of a questionnaire developed by Holahan and Moos (1987). Adjustment was measured in the form of psychological distress and poor role functioning. In addition, event characteristics, situational appraisals, and personal resources such as self-esteem and locus of control were measured. Hierarchical regression analysis indicated that avoidant coping strategies were associated with 
high levels of psychological distress, poor social role functioning and low self-esteem, whereas problem-focused coping was associated with better adjustment and an internal locus of control. The researchers concluded that a failure to deal actively with the stressful situation was associated with poor adjustment, because the use of avoidant strategies meant that acceptance of the reality of the situation was delayed.

Peter and Siegrist (1997) studied the coping patterns of 189 male middle managers and found that those who exhibited passive coping with chronic work stress were significantly more likely to exhibit withdrawal behaviour in the form of sickness absence, while those who made use of active coping were at significantly higher risk of exhibiting manifest hypertension. It should be noted, however, that standardized measuring instruments for coping strategies were not used in this study. Passive coping was conceptualized as low reward in combination with low effort, whereas active coping was conceptualized as low reward in combination with high effort.

In a study of stress and coping associated with downsizing, Kets de Vries and Balazs (1997) explored individual reaction patterns in the victims, the survivors (those staying with a company after layoffs), and the "executioners" (those responsible for the implementation of downsizing - probably mostly managers). Open-ended interviews were conducted within a clinical framework. Special emphasis was given to the reactions of the executives implementing the downsizing operation. Among these subjects, Kets de Vries and Balazs discerned various ways of coping, described as compulsive/ ritualistic, abrasive, dissociative, alexithymic/anhedonic, and depressive. From the interviews it appeared that downsizing, in the narrow sense of the word, could be a quite destructive process. The researchers recommended that the concept should be reframed in order to view downsizing as a continuous process of corporate transformation and change, i.e., a way to plan for the continuity of the organization.

A study of managers' reactions to a corporate acquisition by Fried, Tiegs, Naughton and Ashforth (1996) was based on the assumption that the period following a corporate acquisition is stressful for employees of the acquired company because of the substantial changes in their work environments instituted by the acquiring company. Fried et al. evaluated a proposed model of managers' reactions to the acquisition of their company on the basis of survey data collected from a sample of 91 middle managers whose company was acquired though a hostile takeover by another company. Manifest indicators of change in job control were measured at the beginning of the implementation phase and 16 months later. Managers with increasing levels of external locus of causality were more likely to report greater loss of job control over the 16 -month period. The study thus suggests that locus of control is an important predispositional factor that affects managers' success at maintaining or acquiring more job control in a period in which organizational conditions change dramatically.

A study by Long (1998) seems to suggest that managers may be more successful in coping with stress than clerical employees. Long applied multivariate analysis of variance and multiplegroup structural equation modeling to contrast 214 female clerical workers with 249 managerial women. Consistent with the effects of social roles, clerical workers had fewer coping resources, appraised stressful events as less controllable, experienced more work demands and less support, used relatively less engagement coping, and were more distressed and less satisfied than managers. Moreover, the personality disposition of agentic traits had a stronger influence on coping strategies for clerical workers than for managers.

London (1998) conducted interviews with 90 people from diverse occupational backgrounds who had experienced various types of career barriers such as job loss, discrimination, occupational stress, an abusive supervisor, or a bad business decision. The aim was to examine how people appraise and cope with career barriers. London found that stress was higher for people who adopted more reactive and dysfunctional (emotion-focused) coping strategies (as judged by the interviewer) than those who adopted more proactive and constructive (problem-focused) coping strategies.

Nonis, Sager and Kumar (1996) studied the effect of salespersons' use of upward influence tactics (which may be viewed as their ways of coping) with the sales manager in lessening the impact of two role stressors (perceived role conflict and role ambiguity) on the sales job. It was found that salespeople who perceived high role conflict employed the upward influence tactics of assertiveness and upward appeal more frequently than those with low role conflict. Salespeople who perceived high role ambiguity used exchange and coalition building more frequently than those who experienced low role ambiguity. The results also suggested that salespersons' use of assertiveness and ingratiation exacerbated the relationships between perceived role ambiguity and satisfaction with the manager and propensity to leave. Nonis et al. concluded that, although the use of "hard" upward influence tactics such as upward appeal or coalition building appeared as though they would ameliorate role conflict, such tactics could instead damage the relationship between salesperson and manager.

In a South African study Labuschagne (1994) found, by means of the standardized Experience of Life and Work Circumstances Questionnaire (WLQ) (Van Zyl \& Van der Walt, 1991) that Black middle managers experienced significantly higher stress levels than their White counterparts, although no significant differences existed regarding their coping skills.

No previous study has examined specific coping strategies used by South African managers and their impact on stress levels. The aims of the present study were therefore to examine, by means of a correlational study using standardized measuring instruments, (1) stress levels, predominant stressors and coping strategies in a sample of South African managers, (2) the relationship between stress levels and coping strategies, and (3) the effect of five biographical variables, namely age, gender, ethnic group, marital status and field of management, on managers' stress levels and coping strategies.

\section{METHOD}

\section{Participants}

The sample consisted of 107 fully employed managers, selected from a total group of 190 Master of Business Administration (MBA) students at the Graduate School of Business of the University of Stellenbosch. Of the 107 participants, 90 $(84.1 \%)$ were male and $17(15.9 \%)$ were female; their mean age was $32.7(\mathrm{SD}=5.1) ; 93(86.9 \%)$ were White and $14(13.1 \%)$ were Black. Most of these managers were employed in the manufacturing, personnel, financial and engineering fields. Sixty-four $(59.8 \%)$ were middle managers, $23(21.5 \%)$ were senior managers and $20(18.7 \%)$ were junior managers.

\section{Measuring instruments}

a) A biographical questionnaire was used to obtain information regarding age, sex, ethnicity, marital status and field of management.

b) The Experience of Work and Life Circumstances Questionnaire (WLQ) (Van Zyl \& Van der Walt, 1991, 1994), a standardized South African stress questionnaire developed by the Human Sciences Research Council (HSRC) on the basis of the transactional model of stress (Cox \& MacKay, 1981; Lazarus \& Folkman, 1984) was used to measure stress. The WLQ contains 115 items which measure respondents' appraisal of six work-related stressor domains, namely organizational functioning; physical working conditions; career matters; task characteristics; social matters; remuneration, fringe benefits and personnel policy; as well as circumstances outside work. Respondents indicate their appraisal of these stressor domains on a five-point scale. A 
lower score indicates poorer appraisal, i.e. that the specific domain is appraised as more stressful. The WLQ also yields a stress level score consisting of the total score on several emotional indicators of stress, such as anxiety, depression, frustration and aggression. The WLQ possesses construct validity, because the expected correlations with relevant tests have been found (Van Zyl,1998). A Kuder-Richardson reliability coefficient of .8 and test-retest reliability coefficients varying between .62 and .92 have been found, comparing favourably with reliability coefficients reported for other similar questionnaires (Van Zyl, 1998). The WLQ has been used successfully to examine stress levels in South African managers by Labuschagne (1994).

c) The Coping Strategy Indicator (CSI) (Amirkhan, 1990, 1994), a 33-item self-report measure based on Lazarus and Folkman's (1984) Ways of Coping questionnaire, was used to determine to which extent participants used three basic coping strategies, namely problem-solving, avoidance and seeking social support. The CSI possesses high test-retest reliability and internal consistency (Amirkhan, 1990,1994), as well as satisfactory convergent and discriminant validity (Amirkhan, 1990, 1994; Ptacek, Smith, Espe \& Rafferty, 1994). The CSI has been used successfully in previous South African studies of psychological well-being (Spangenberg \& Theron, 1999, Wissing \& Du Toit, 1994).

\section{Procedure}

The questionnaires comprising the measuring instruments were completed with informed consent on a voluntary and anonymous basis during a class period under the supervision of the second author.

\section{RESULTS}

The mean stress level of the total group was within the normal range. To neutralize the masking potential of the total mean score, cluster analysis was conducted by means of the Ward 2 cluster sampling procedure. Two biographically homogeneous clusters (who did not differ significantly on any of the biographical variables) were thus identified. The stress level score of Cluster $A(n=52 ; 48.6 \%)(M=81.75, S D=12.72)$ was significantly higher than that of Cluster $B(n=55 ; 51.4 \%)(M=63.73$, $\mathrm{SD}=9.44)(\mathrm{F}=69.79, \mathrm{p}<$.001). The mean stress level of Cluster $\mathrm{A}$ was in the high range according to the WLQ $(80+)$, while the mean stress level of Cluster B was in the normal range (40-79). Each of the six work-related stressor domains (but not circumstances outside work) was appraised significantly more negatively by Cluster A (the cluster with high stress levels) than by Cluster B (all p c .001).

Three stressor domains, namely organizational functioning, career matters, as well as remuneration, fringe benefits and personnel policy, were appraised as highly stressful by Cluster A participants, according to the WLQ cutoff scores, whereas the other stressor domains were appraised as moderately stressful. Cluster A made significantly more use of an avoidant coping strategy than Cluster $B(F=7.17, p<.01)$.

Significant negative Pearson correlations were found between the total sample's stress level scores and appraisal scores on all six stressor domains relating to the work situation. This implies that, the higher their stress levels, the more negative was their appraisal of their working conditions (i.e., the more stressful they experienced these potential stressors). Interestingly, this negative correlation did not apply to circumstances outside work, where a positive correlation was found (see Table 1).

Analysis of variance (ANOVA) showed that only an avoidant coping strategy explained significant variance in stress levels for the total group (see Table 2).

ANOVA indicated that female managers' stress levels $(M=79.35, S D=12.22)$ were significantly higher than those of male managers $(\mathrm{M}=71.19, \mathrm{SD}=14.38)(\mathrm{F}=4.81, \mathrm{p}<.05)$. No significant differences in stress levels were found regarding the other biographical variables examined.

Table 1

Pearson Correlations between Stress Levels and Stressor Domain Scores on the WLQ for the Total Sample $(\mathrm{N}=107)$

\begin{tabular}{lcc}
\hline Stressor Domain & $\mathrm{r}$ & $\mathrm{p}$ \\
\hline Organizational functioning & -.506 & $<.001$ \\
Physical working conditions & -.327 & $<.001$ \\
Career matters & -.533 & $<.001$ \\
Task characteristics & -.627 & $<.001$ \\
Social matters & -.609 & $<.001$ \\
Remuneration, fringe benefits & & \\
and personnel policy & -.494 & $<.001$ \\
Circumstances outside work & .463 & $<.001$ \\
\hline
\end{tabular}

Table 2

Analysis of Variance of Stress Level Scores according to Coping Strategies $(\mathrm{N}=107)$

\begin{tabular}{lccccc}
\hline Source & $\mathrm{df}$ & $\mathrm{SS}$ & $\mathrm{MS}$ & $\mathrm{F}$ & $\mathrm{p}$ \\
\hline Problem-solving & 1 & 590.6 & 590.6 & 3.37 & .07 \\
Avoidance & 1 & 3075.1 & 3075.1 & 17.53 & $.0001 \star \star \star$ \\
Seeking social support & 1 & 6.9 & 6.9 & .04 & .84 \\
Error & 103 & 18069.6 & 175.4 & & \\
\hline TOTAL & 106 & 21744.7 & & & \\
$\star \star \star \mathrm{p}<.001$ & & & & &
\end{tabular}

Regarding coping strategies, ANOVA indicated that female managers used a social support-seeking coping strategy significantly more than male managers did $(\mathrm{F}=8.71, \mathrm{p} \times .01)$. No significant difference between males and females were found regarding the use of problem-solving and avoidant coping strategies.

\section{DISCUSSION}

The finding that the mean stress level of this group of managers was within the normal range is in accordance with that of Labuschagne (1994), who also used the WLQ and found average stress levels in her sample of middle managers. However, in the present study cluster analysis identified two biographically homogeneous clusters within the total sample and neutralized the masking potential of the total mean score. One cluster consisting of 52 participants $(48.6 \%)$ experienced high stress levels, which is in line with the findings of Strümpfer (1989) and Van Zyl (1993) that many South African managers suffered from high stress levels.

It is meaningful that the cluster with high stress levels also appraised all six work stressor domains, namely organizational functioning; physical working conditions; career matters; task characteristics; social matters; and remuneration, fringe benefits and personnel policy, but not circumstances outside work, in a significantly more negative manner than the cluster with normal stress levels. In addition, they used an avoidant coping strategy to a significantly greater extent than the cluster with normal stress levels. This combination seems to suggest the contribution of negative appraisal and avoidance to high stress levels.

This suggestion was confirmed by the significant negative correlations, not only in the cluster with high stress levels but in the total group, between managers' stress levels and appraisal of all six work-related stressor domains. In addition to confirming the validity of the measuring instruments, these correlations clearly indicate that, the more negative the appraisal of stressor domains, the higher the stress levels were and vice versa. It must be kept in mind, though, that although negative appraisal of stressor domains could have contributed to high stress levels, inherently high stress levels could also have contributed to negative appraisal. 
Avoidance was the only coping strategy that explained significant variance in the stress levels of the managers. It therefore seems as if an avoidant coping strategy contributed to higher stress levels. This finding is in line with those of Terry and Callan (1997), who found that avoidant coping strategies used by managers were related to high levels of psychological distress as well as to poor social role functioning and low self-esteem. The present finding is also comparable to that of Peter and Siegrist (1997), who found that passive coping was related to withdrawal and "giving up" behaviour in terms of sickness absence, although Peter and Siegrist did not measure stress levels or use standardized coping questionnaires. In addition, the present finding is in accordance with previous findings regarding the relationship between an avoidant coping strategy and stress in other research populations, including normal populations (Nakano, 1991), spouses of depressed patients (Spangenberg \& Theron, 1999) and recently detoxified alcoholics (Campbell \& Spangenberg, 1999). The present finding suggests that avoidance, when used by managers as a coping strategy, is a destructive strategy which creates stress as a result of inevitably poorer work performance and accumulation of problems due to avoiding issues instead of confronting them in a constructive way. Managerial stress management courses should therefore emphasize the healthy coping strategy of actively confronting problem situations instead of avoiding them, as well as the psychologically sound coping strategy of mobilizing social support in the work situation in an appropriate manner.

The only biographical variable that had an effect on stress levels, as well as on coping strategies, was gender. Firstly, female managers had significantly higher stress levels than male managers. This finding is at variance with Martocchio and O'Leary's (1989) meta-analysis of 15 empirical studies which indicated no gender differences in physiological and psychological stress in occupational settings. However, findings that are in line with those of the present study were recently reported by Babin and Boles (1998), who reported that increased role stress affected female service providers' job performance more negatively than that of males. The present finding also shows interesting parallels with those of Jackson, Thoits and Taylor (1995) who reported that, in a study of 167 black leaders, the positive correlation found between anxiety and oppositegender representation remained statistically significant when role overload and other stressors were held constant. They found that numerical rarity on the basis of gender and ethnicity (a phenomenon related to 'tokenism') showed significant correlations with increased stress levels and seeking social support. In view of the small number of female managers in the present study $(15.9 \%)$, the present finding may likewise imply that gender as such does not have discriminatory value, but that numerical rarity does.

The finding that female managers used a social support-seeking coping strategy to a greater extent than their male counterparts may be a reflection of the female participants' higher stress levels. However, it may also reflect the general tendency among women to have a higher level of the need for affiliation and to be more concerned with achieving acceptance and good social interaction at work than men (Gerdes, 1988).

The role of gender as a possible predictor of the level of experienced stress in South African managers thus needs to be investigated further. It is possible that in the South African managerial system, which is still to a large extent male-dominated, female managers experience more role conflict, role ambiguity and work/home conflict than their USA counterparts and that this contributed to the higher stress levels of the female managers in the present study. Gender differences should be taken into consideration in the development of managerial stress management programs.

In summary, this study showed that high stress levels in managers correlated with negative appraisal of the work situation, that an avoidant coping strategy probably contributed to high stress levels, that female managers experienced higher stress levels than their male counterparts, and that social support played an important role in the coping repertoire of female managers.

A limitation of the present study is the fact that an indicental sample was used, consisting of managers involved in an MBA course. MBA students form a select group which does not represent the fields of management, managerial levels, ethnic distribution and system composition of all South African managers. The present results can therefore not be generalized to the broad field of South African managers, but only to managers pursuing a postgraduate managerial qualification. It is recommended that this study be followed up by a study of a fully representative sample of South African managers.

\section{REFERENCES}

Amirkan, J.H. (1990). A factor analytically derived measure of coping: The Coping Strategy Indicator. Journal of Personality and Social Psychology, 59, 1066-1074.

Amirkan, J.H. (1994). Criterion validity of a coping measure. Journal of Personality Assesment, 62, 242-261.

Antonovsky, A. (1990). Pathways leading to successful coping in health. In Learned resourcefulness: On coping skills, self-control, and adaptive behaviour (pp. 31-63). New York: Springer.

Antonovsky, A. (1991). The structural sources of salutogenic strengths. In C.L. Cooper \& R. Payne (Eds), Personality and stress: Individual differences in the stress process (pp. 67-104). New York: Wiley.

Babin, B.J., \& Boles, J.S. (1998). Employee behavior in a service environment: A model and test of potential differences between men and women. Journal of Marketing, 62, 77-91.

Beehr, T.A. (1995). Psychological stress in the workplace. London: Routledge.

Campbell, M.E., \& Spangenberg, J.J. (1999). Stress and coping strategies in recently detoxified alcoholics. Urban Health and Development Bulletin, 2, 58-62.

Cox, T., \& Mackay, C. (1981). A transactional approach to occupational stress. In E.N. Corlett \& J. Richardson (Eds.), Stress, work design and productivity (pp.210-259). Chichester: Wiley \& Sons.

Daniels, K. (1996). Why aren't managers concerned about occupational stress? Work and Stress, 10, 352-366.

Executive stress and the art of balanced living. (1991, December). Rehabilitation in South Africa, 102-104.

Fried, Y., Tiegs, R.B., Naughton, T.J., \& Ashforth, B.E. (1996). Managers' reactions to a corporate acquisition: A test for an integrative model. Journal of Organizational Behaviour, 17, 401-427.

Gerdes, L.C. (1988). The developing adult ( $2^{\text {nd }}$ ed.). Durban: Butterworths.

Holahan, C.J., \& Moos, R.H. (1987). Personal and contextual determinants of coping strategies. Journal of Personality and Social Psychology, 52, 946-955.

Holahan, C.J., \& Moos, R.H. (1990). Life stressors, resistance factors, and improved psychological functioning: An extension of the stress resistance paradigm. Journal of Personality and Social Psychology, 58, 909-917.

Jackson, P.B.,Thoits, P.A., \& Taylor, H.F. (1995). Composition of the workplace and psychological well-being: The effects of tokenism on America's black elite. Social Forces, 74, 543-557.

Katz, D., \& Kahn, R.L. (1978). The social psychology of organizations $\left(2^{\text {nd }}\right.$ ed.). New York: Wiley.

Kets de Vries, M.F.R., \& Balazs, K. (1997). The downside of downsizing. Human Relations, 50, 11-50.

Labuschagne, K. (1994). Werkstres en hanteringsmeganismes van afrosentriese en eurosentriese middelvlak bestuurders (Job stress and coping mechanisms of afrocentric and eurocentric midlevel managers). Unpublished masters thesis, Rand Afrikaans University, Johannesburg, South Africa.

Lazarus, R.S., \& Folkman, S. (1984). Stress, appraisal, and coping. New York: Springer.

London, M. (1998). Career barriers: How people experience, overcome, and avoid failure. Mahwah, NJ: Lawrence Erlbaum Associates.

Long, B.C. (1998). Coping with workplace stress: A multiple- 
group comparison of female managers and clerical workers. Journal of Counseling Psychology, 45, 65-78.

Martocchio, J.J., \& O'Leary, A.M. (1989). Sex differences in occupational stress: A meta-analytic review. Journal of Applied Psychology, 74, 495-501.

Nakano, K. (1991). Coping strategies and psychological symptoms in a Japanese sample. Journal of Clinical Psychology, 47, 346-350.

Nonis, S.A., Sager, J.K., \& Kumar, K. (1996). Sales peoples' use of upward influence tactics (UITs) in coping with role stress. Journal of the Academy of Marketing Science, 24, 44-56.

Peter, R., \& Siegrist, J. (1997). Chronic work stress, sickness absence and hypertension in middle managers: General or specific sociological explanations? Social Science and Medicine, 45, 1111-1120.

Ptacek, J.T., Smith, R.E., Espe, K., \& Raffety, B. (1994). Limited correspondence between daily coping reports and retrospective coping recall. Psychological Assessment, 6, 41-49.

Smyth, K.A., \& Williams, P.D. (1991). Patterns of coping in black working women. Behavioural Medicine, 17, 40-46.

Spangenberg, J.J., \& Theron, J.C. (1999). Stress and coping in spouses of depressed patients. The Journal of Psychology, 133, 253-262.

Strümpfer, D.J.W. (1989). Do white South African managers suffer from exceptional levels of job stress? South African Journal of Psychology, 19, 130-137.
Strümpfer, D.J.W. (1990). Salutogenesis: A new paradigm. South African Journal of Psychology, 20, 265-276.

Terry, D.J., \& Callan, V.J. (1997). Employee adjustment to largescale organisational change. Australian Psychologist, 32, 203210.

Van Zyl, E.S. (1993). Stres, soos ervaar deur die hoëvlak swart werknemer in Suid-Afrika. (Stress, as experienced by the high-level black employee in South Africa.) Journal of Industrial Psychology, 19, 36-39.

Van Zyl, E.S. (1998). Die effek van regstellende aksie op die stres ervaring van 'n groep swart werknemers. (The effect of affirmative action on the stress experience of a group of black employees.) Journal of Industrial Psychology, 24, 22-25.

Van Zyl, E.S., \& Van der Walt, H.S. (1991). Manual for the Experience of Work and Life Circumstances Questionnaire. Pretoria: Human Sciences Research Council.

Van Zyl, E.S., \& Van der Walt, H.S. (1994). Die ontwikkeling van 'n meetinstrument van werkstres. (The development of a measuring instrument of job stress.) Journal of Industrial Psychology, 20, 22-28.

Wissing, M.P., \& Du Toit, M.M. (1994). Relations of NEO-PI-R dimensions (NEO-FFI) to sense of coherence (SOC) and other measures of psychological well-being. Paper presented at the 23rd International Congress of Applied Psychology, Madrid, Spain. 